Dinamika Sosial Budaya, Vol 20, No. 1, Juni 2018, pp 16-29

p-ISSN: 1410-9859\& e-ISSN: 2580-8524

http://journals.usm.ac.id/index.php/jdsb

\title{
MODEL PEMBUKUAN SEDERHANA UKM BAKSO KLASTER SEMI MODERN DI WILAYAH KOTA SEMARANG
}

\section{SIMPLE BOOKKEEPING MODEL SMES SEMI MODERN CLASTER BAKSO IN THE SEMARANG CITY}

\author{
C Tri Widiastuti \\ Program Studi Akuntansi, Fakultas Ekonomi, Universitas Semarang, \\ Aprih Santoso \\ Program Studi Akuntansi, Fakultas Ekonomi, Universitas Semarang \\ Anandha \\ Program Studi Akuntansi, Fakultas Ekonomi, Universitas Semarang
}

\begin{abstract}
Financial book keeping will result in a more informative financial report in order to provide complete information to third parties. But in practice the owner of SMEs are unable to provide financial information in the absence of financial statements. Low quality of human resources and lack of understanding of financial statements are the reason why SMEs owners do not make financial reports. This study aims to analyze financial bookkeeping that has been done and designed a simple financial bookkeeping model for the owner of SMEs semi-modern cluster bakso in the city of Semarang. The research method used is qualitative with data collection techniques through in-depth interviews conducted on key informants. Informants in this study are the owner of SMEs bakso in the city of Semarang. Data analysis techniques using Miles and Hubermans model with stages include: data reduction, data presentation and conclusion drawing/verification. While the data validity test using credibility test through extension of observation and trianggulasi.
\end{abstract}

Keywords: Financial Bookkeeping, Financial Statements, SMEs

\begin{abstract}
Abstrak
Pembukuan keuangan akan menghasilkan suatu laporan keuangan yang lebih informatif agar dapat memberikan informasi yang lengkap pada pihak ke tiga. Namun pada prakteknya pemilik UKM tidak mampu memberikan informasi keuangan karena tidak adanya laporan keuangan. Kualitas SDM yang rendah dan kurangnya pemahaman tentang laporan keuangan menjadi alasan pemilik UKM untuk tidak membuat laporan keuangan. Penelitian ini bertujuan untuk menganalisa pembukuan keuangan yang selama ini dilakukan dan mendesain model pembukuan keuangan sederhana untuk pemilik UKM bakso klaster semi modern di wilayah kota Semarang. Metode penelitian yang digunakan adalah kualitatif dengan teknik pengumpulan data melalui wawancara mendalam yang dilakukan pada key informan. Informan dalam penelitian ini adalah pemilik UKM

bakso di wilayah kota Semarang. Teknik analisis data menggunakan model Miles and Hubermans dengan tahapan mencakup: reduksi data (data reduction), penyajian data (data display) serta penarikan kesimpulan dan verifikasi (conclusion drawing/verification). Sedangkan uji keabsahan data menggunakan uji kredibilitas melalui perpanjangan pengamatan dan trianggulasi.

Kata kunci: Pembukuan Keuangan, Laporan Keuangan, UKM
\end{abstract}


Dinamika Sosial Budaya, Vol 20, No. 1, Juni 2018, pp 16-29

p-ISSN: 1410-9859\& e-ISSN: 2580-8524

http://journals.usm.ac.id/index.php/jdsb

\section{PENDAHULUAN}

\subsection{Latar Belakang}

Usaha kecil merupakan salah satu pilar ekonomi kerakyatan untuk mewujudkan pemerataan kesempatan bagi seluruh masyarakat untuk berusaha secara mandiri dalam rangka meningkatkan taraf hidup dan diharapkan dapat mengurangi kesenjangan pendapatan. Keberadaan usaha kecil yang sangat besar mampu mewakili hampir seluruh unit usaha di berbagai sektor ekonomi yang hidup dalam perekonomian. Di masa krisis usaha kecil dan menengah dinilai masih mampu bertahan bahkan mampu berkembang, karena fleksibilitasnya dan ketidak tergantungannya pada pembiayaan melalui kredit perbankan. Peran UKM menurut Prof. Urata (2000) mencakup 1) pemain utama dalam kegiatan ekonomi di Indonesia, 2) penyedia kesempatan kerja yang menaik, 3) pemain penting dalam pengembangan ekonomi lokal dan pengembangan masyarakat, 4) pencipta pasar dan inovasi baru melalui fleksibilitas dan sentivitas UKM serta keterkaitan dinamis antar kegiatan perusahaan, dan 5) pemain dalam perbaikan neraca pembayaran internasional melalui peran yang semakin nyata dalam komposisi ekspor dan penghematan devisa melalui produkproduk subtitusi impor yang dikaitkan oleh UKM. Bukti bahwa UKM mampu memberikan kontribusi pada perekonomian di Indonesia didukung oleh data dari Kementerian Koperasi dan UKM menunjukkan bahwa pada tahun 2016 Kontribusi UMKM terhadap Produk Domestik Bruto (PDB) tahun 2016 mencapai 60 persen menuju 70 persen. Dari jumlah tersebut 30,3 persen disumbang oleh usaha mikro, (www.depkop.go.id). Sampai dengan tahun 2015 jumlah unit UMKM di Indonesia mencapai 72,2 juta unit usaha yang tersebar di seluruh wilayah Indonesia.
Salah satu jenis UKM yang berpotensi untuk dikelola dan dikembangkan yakni UKM yang bergerak dibidang kuliner. Salah satu kuliner yang banyak tumbuh yakni kuliner bakso yang sangat digemari karena rasanya yang lesat. UKM bakso merupakan sebuah peluang usaha yang tidak dapat diabaikan. Semakin menjamurnya usaha bakso menunjukkan pula adanya peningkatan jumlah UKM yang bekerja secara mandiri, mampu menciptakan lapangan kerja baru dimana tiap usaha bakso umumnya mempekerjakan beberapa orang karyawan, serta mampu memenuhi kebutuhan pangan masyarakat secara luas karena keberadaannya mudah diakses masyarakat.

UKM bakso di wilayah kota Semarang terdiri dari tiga kelompok yakni 1) Paguyuban P3BS yakni paguyuban pedagang bakso wilayah Semarang Barat, Utara dan Tengah, 2) Paguyuban Manunggal Jaya yakni paguyuban pedagang bakso wilayah Genuk Sayung dan sekitarnya dan 3) Paguyuban Sido Rukun yakni paguyuban pedagang bakso wilayah semarang Timur, Selatan, Mranggen. Dimana masing-masing kelompok terdiri dati tiga klaster yakni tradisional, semi modern dan modern. Masing-masing klaster mempunyai perilaku yang berbeda dalam menjalankan usahanya (Tri Widiastuti, dkk. 2017). Pada klaster tradisional, perilaku pemilik UKM bakso dalam menjalankan usaha perlu banyak bimbingan dan perubahan mindset dalam berwirausaha karena SDM nya sangat rendah dan sangat tradisional. Pada klaster semi modern, pemilik UKM mempunyai keinginan untuk mengembangkan usahanya. Sedangkan pada klaster modern, pemilik UKM yang sudah mempunyai inovasi dalam menjalankan usaha bakso. 
Dinamika Sosial Budaya, Vol 20, No. 1, Juni 2018, pp 16-29

p-ISSN: $1410-9859 \&$ e-ISSN: $2580-8524$

http://journals.usm.ac.id/index.php/jdsb

Dalam penelitian ini, peneliti akan fokus pada klaster semi modern. Kualitas SDM UKM bakso pada klaster semi modern masih rendah, baik dilihat dari segi pendidikan formal maupun pengetahuan dan keterampilannya sangat berpengaruh terhadap manajemen pengelolaan usahanya. Dengan keterbatasan kualitas sumber daya manusia nya UKM bakso pada klaster ini sulit untuk berkembang dengan optimal dan sulit untuk mengadopsi perkembangan teknologi baru untuk meningkatkan daya saing usahanya. Masalah yang dihadapi UKM bakso pada klaster semi modern di wilayah kota Semarang terutama terkait dengan pencatatan keuangan, pemilik UKM bakso cenderung mengabaikan pentingnya melakukan pencatatan keuangan. Dari sisi keuangan, pemilik UKM tidak memisahkan antara kebutuhan modal kerja dengan kebutuhan rumah tangga.

Tidak teridentifikasi berapa laba riil yang didapatkan dari penjualan untuk menopang modal dan menopang kebutuhan rumah tangga. Dawuda (2015) mengungkapkan bahwa efek bagi pemilik UKM yang tidak melakukan pencatatan keuangan dengan baik adalah pemilik tidak dapat melakukan analisis keuangan untuk mengetahui apakah bisnis mereka berjalan dengan baik atau tidak. Mereka tidak dapat memahami dan memprediksi lingkungan bisnis dan hal ini dapat menyebabkan kegagalan bisnis. Pengelolaan modal kerja yang efektif juga akan menjadi masalah bagi mereka tanpa menyimpan catatan keuangan yang baik. Catatan keuangan yang tidak memadai atau buruk mempengaruhi pengguna seperti lembaga pemerintah, lembaga keuangan, investor dan pengguna lainnya dalam pengambilan keputusan dan perencanaan ekonomi. Pencatatan keuangan yang buruk akan menyebabkan kinerja keuangan menjadi buruk dan catatan keuangan yang baik,

tertib dan teratur dapat menjaga kinerja keuangan perusahaan skala kecil yang lebih baik (Rahomon, 2014).

Penelitian yang akan dilakukan dalam upaya untuk meningkatkan kemampuan pembukuan keuangan pada pelaku UKM Bakso di wilayah Kota Semarang adalah menggali permasalahan yang muncul dalam pembukuan keuangan dan model pembukuan keuangan yang sesuai dengan kondisi pemilik UKM Bakso di Wilayah Kota Semarang pada klaster semi modern. Model Pembukuan sederhana merupakan upaya meningkatkan kemampuan mencatat keuangan secara sistematis, komprehensif dan berkelanjutan.

\subsection{Rumusan Masalah}

Dengan mendasarkan identifikasi masalah tersebut di atas, maka permasalahan-permasalahan penelitian dalam kaitannya dengan model pembukuan sederhana berbasis klaster UKM bakso di wilayah kota Semarang dapat dirumuskan sebagai berikut:

1. Bagaimanakah pembukuan keuangan pemilik UKM bakso klaster semi modern di wilayah Kota Semarang?

2. Bagaimanakah desain model pembukuan keuangan pemilik UKM bakso klaster semi modern di wilayah Kota Semarang ?

\subsection{Tujuan Penelitian}

Tujuan yang diharapkan dari hasil penelitian berkait model pembukuan sederhana UKM bakso klaster semi modern di wilayah kota Semarang mencakupi:

1. Menganalisa pembukuan keuangan pemilik UKM bakso klaster semi modern di wilayah Kota Semarang

2. Mendesain model Pembukuan Keuangan pemilik UKM Bakso klaster semi modern di wilayah kota Semarang. 
Dinamika Sosial Budaya, Vol 20, No. 1, Juni 2018, pp 16-29

p-ISSN: 1410-9859\& e-ISSN: 2580-8524

http://journals.usm.ac.id/index.php/jdsb

\section{Tinjauan Pustaka}

\subsection{UMKM}

Di Indonesia Usaha Mikro Kecil dan Menengah UMKM merupakan usaha yang memiliki peran yang cukup tinggi dalam menopang perekonomian negara. Seiring dengan perkembangan waktu jumlah UMKM semakin meningkat, dengan meningkatnya jumlah UMKM maka akan semakin banyak penciptaan kesempatan kerja bagi para pengangguran. Disamping itu UMKM dapat dijadikan sebagai sumber pendapatan khususnya di daerah pedesaan dan rumah tangga berpendapatan rendah. Peran UMKM tidak dapat di ragukan lagi dalam mendukung peningkatan pendapatan masyarakat tetapi pengertian dari UMKM tersebut masih beragam dan makna dari UMKM sendiri berbeda beda. Definisi yang berkaitan dengan UMKM antara lain menurut: 1) Ketentuan undang undang No. 9 Tahun 1995 tentang usaha kecil dan kemudian dilaksanakan lebih lanjut dengan peraturan pemerintah nomor 44 tahun 1997 tentang kemitraan, dimana pengertian UMKM adalah sebagaimana di atur Undang-undang No. 20 tahun

2008 UMKM adalah usaha ekonomi produktif yang berdiri sendiri, yang dilakukan oleh perorangan atau badan usaha yang bukan merupakan anak perusahan atau bukan cabang yang dimiliki, dikuasai atau menjadi bagian baik langsung maupun tidak langsungdari usaha menengah atau usaha besar yang memenuhi kriteria usaha kecil; 2) Menurut jumlah tenaga kerja, usaha kecil adalah usaha yang mempunyai tenaga kerja sebanyak 5 sampai 9 orang tenaga kerja. Industri rumah tangga adalah industri yang memperkerjakan kurang dari 5 orang. UMKM adalah usaha yang mempunyai modal awal yang kecil atau nilai kekayaan (aset) yang kecil dan jumlah pekerja yang kecil (terbatas), nilai modal (aset) atau jumlah pekerjaannya sesuai definisi yang diberikan oleh pemerintah atau intitusi lain dengan tujuan tertentu (Sukirno, 2004: 365)

\subsection{Laporan Keuangan}

Pembukuan transaksi keuangan seringkali disamakan dengan akuntansi, informasi yang terdapat di dalam pembukuan atau akuntansi dasar mempunyai peranan penting untuk mencapai keberhasilan usaha bagi pemilik maupun pengelola usaha mikro. Pada kenyataannya pemilik usaha hanya mencatat jumlah uang yang diterima dan dikeluarkan, jumlah barang yang dibeli dan dijual, dan jumlah piutang atau utang. Namun pencatatan itu hanya sebatas pengingat saja dan tidak dengan format yang memudahkan untuk menyusun laporan keuangan sesuai dengan prinsip akuntansi yang berlaku.

Laporan keuangan yang pada mulanya hanyalah sebagai alat penguji dari pekerjaan bagian pembukuan, untuk selanjutnya juga digunakan sebagai dasar untuk dapat menentukan atau menilai posisi keuangan perusahaan, kemudian dengan hasil penilaian tersebut pihak-pihak yang berkepentingan membuat suatu keputusan. Jadi laporan keuangan diperlukan untuk mengetahui posisi keuangan dari suatu perusahaan dan hasil-hasil yang telah dicapai oleh perusahaan tersebut selama kurun waktu tertentu. Beberapa pengertian dari laporan keuangan yakni 1) Laporan keuangan pada dasarnya adalah hasil dari proses akuntansi yang dapat digunakan sebagai alat untuk berkomunikasi antara data keuangan atau aktivitas suatu perusahaan dengan pihak-pihak yang berkepentingan dengan data atau aktivitas perusahaan tersebut (S. Munawir,2004:2); 2) Laporan keuangan adalah laporan 
Dinamika Sosial Budaya, Vol 20, No. 1, Juni 2018, pp 16-29

p-ISSN: $1410-9859 \&$ e-ISSN: $2580-8524$

http://journals.usm.ac.id/index.php/jdsb

pertanggungjawaban manajer/pimpinan perusahaan atas yang dipercayakan kepada pihak-pihak yang mempunyai kepentingan (stockholders) diluar perusahaan, pemilik perusahaan, pemerintah, kreditur dan pihak lainnya (Budi Raharjo,2005:1); 3) Sedangkan menurut Miswanto dan Eko Widodo (1998:80), Laporan keuangan merupakan media informasi yang digunakan oleh perusahaan yang bersangkutan untuk melaporkan keadaan dan posisi keuangannya kepada pihakpihak yang berkepentingan, terutama bagi pihak kreditur, investor, dan pihak manajemen dari perusahaan itu sendiri.

Dengan melakukan analisa laporan keuangan suatu perusahaan akan sangat bermanfaat bagi penganalisa untuk mengetahui keadaan perkembangan financial perusahaan dan dapat segera mengetahui kelemahan dan kelebihan dari perusahaan tersebut.

\subsection{Penelitian Terdahulu Yang Relevan}

Hasil penelitian terdahulu mengungkapkan bahwa pemilik yang memahami isi dan nilai laporan keuangan cenderung menggunakan informasi dari laporan keuangan untuk mengambil keputusan dimana keputusan yang diambil dipengaruhi oleh beberapa faktor dari usahanya (Carraher, 2013). Dengan laporan keuangan pemilik UKM mempunyai pengetahuan yang baik terkait dengan usahanya ,lebih berpengalaman dan percaya diri dalam mengambil keputusan (Vanauken,2016). Sedangkan menurut Juric (2014) laporan keuangan dapat menunjukkan kinerja keuangan, temuan dari penelitian ini bahwa laporan keuangan mampu memberikan informasi perkembangan usahanya. Dengan melakukan penyimpanan catatan bisnis, pengelolaan keuangan, pengelolaan kredit baik pembayaran maupun penagihan dari laporan keuangan menunjukkan bahwa kemampuan menyusun laporan keuangan yang dimiliki pelaku UKM mempengaruhi kinerja usaha yang dijalankan (Nurlaila, 2014). Dan hasil penelitian Andriani (2014) mengungkapkan bahwa sistem pencatatan keuangan yang UMKM dilakukan secara manual dan masih sangat sederhana beberapa faktor yang membuat pencatatan keuangan tidak sesuai dengan standar akuntansi yakni faktor internal berupa kurangnya pemahaman, kedisiplinan dan sumber daya manusia, serta faktor eksternalnya karena kurangnya pengawasan dari stakeholder yang berkepentingan dengan laporan keuangan. Dalam menjalankan usaha laporan keuangan sangat penting untuk menilai kinerja keuangan perusahaaan.

\subsection{Kerangka Berfikir}

Pembukuan keuangan perusahaan menghasilkan laporan keuangan. Keterbatasan pengetahuan pembukuan akuntansi, rumitnya proses akuntansi membuat pemilik UKM enggan melakukan pembukuan keuangan dan menganggap laporan keuangan tidak penting bagi pemilik UKM (Jati et.al., 2009). Pembukuan keuangan merupakan alat atau sarana yang dipakai pemilik UKM untuk memperoleh informasi kondisi keuangan perusahaan. Informasi tentang keuangan dapat digunakan untuk berkomunikasi dengan pihak lain yang berkepentingan terhadap usahanya. Pembukuan keuangan sangat baik bagi internal maupun eksternal dari usaha yang dijalankan, banyak pihak yang membutuhkan, karena dari pembukuan keuangan yang tertib dan teratur pemilik UKM dapat mengambil keputusan yang tepat terkait dengan usahanya, serta dapat mengurai kompleksitas permasalahan yang terjadi pada pemilik UKM Bakso pada klaster semi modern di wilayah di Kota Semarang. Kompleksitas 
Dinamika Sosial Budaya, Vol 20, No. 1, Juni 2018, pp 16-29

p-ISSN: 1410-9859\& e-ISSN: 2580-8524

http://journals.usm.ac.id/index.php/jdsb

permasalahan tersebut mencakup: 1) Kualitas

pendidikan SDM yang rendah, 2) ketidak mampuan

dalam tata tertib pencatatan/pembukuan; 3)

banyak pemilik UKM bakso yang belum memiliki

badan hukum yang jelas; 4) pemilik UKM Bakso

dinilai masih kurang menguasai teknologi dan

manajemen keuangan; serta

5) minimnya pemilik UKM bakso mengakses

kebijakan-kebijakan pemerintah dalam program pengembangan UKM.

Pembukuan keuangan sederhana bagi

pemilik UKM Bakso berbasis klaster semi modern merupakan upaya bagi pemilik UKM bakso dalam upaya meningkatkan kemampuan untuk mengambil keputusan dan daya ungkit usahanya. UKM diharapkan mampu melakukan pembukuan akuntansi untuk menyajikan laporan keuangan yang lebih informatif dengan tujuan tentunya memberikan informasi bagi investor maupun kreditor mengenai kondisi perusahaannya (Rudiantoro dan Siregar, 2011). Kerangka berpikir penelitian dapat ditunjukkan pada Gambar 1 Pengambilan Keputusan

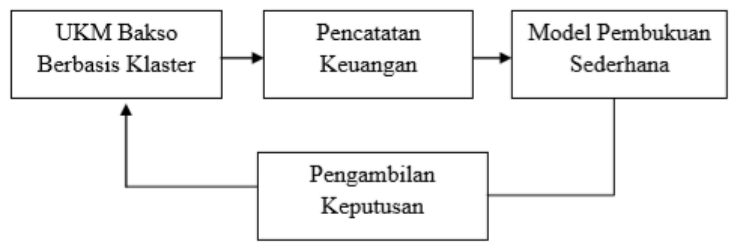

Gambar.1 Kerangka Berpikir

\section{Metode Penelitian}

\subsection{Pendekatan Penelitian}

Pendekatan penelitian model pembukuan sederhana berbasis klaster UKM bakso di wilayah kota Semarang menggunakan pendekatan kualitatif, karena baik subyek, obyek maupun sifat penelitian ini memiliki ciri khusus yang tidak bisa didekati dengan prosedur statistik. Metode penelitian ini merupakan suatu proses eksplorasi dan memahami makna perilaku individu atau kelompok, menggambarkan masalah sosial atau masalah kemanusiaan. Proses penelitian mencakup membuat pertanyaan penelitian dan prosedur yang masih bersifat sementara, mengumpulkan data pada seting partisipan, analisis data secara induktif, membangun data yang parsial ke dalam tema, dan selanjutnya memberikan interprestasi terhadap makna suatu data. Tahap-tahap yang harus dilakukan dalam metode penelitian kualitatif mencakupi: 1) tahap mencari informasi yakni mendeskripsikan apa yang dilihat, didengar, dirasakan dan ditanyakan; 2) tahap reduksi/fokus yakni peneliti mereduksi segala informasi yang telah diperoleh pada tahap pertama, 3) tahap seleksi, pada tahap ini peneliti menguraikan fokus yang telah ditetapkan menjadi lebih rinci. Setelah peneliti melakukan analisis yang mendalam terhadap data dan informasi yang diperoleh, maka peneliti dapat menemukan temuannya. Proses memperoleh data atau informasi pada setiap tahapan (deskripsi, reduksi, seleksi) tersebut dilakukan secara sirkuler, berulang-ulang dengan berbagai cara dan dari berbagai sumber

\subsection{Tempat Penelitian}

Tempat penelitian dalam kaitannya dengan model pembukuan sederhana berbasis klaster UKM Bakso di wilayah kota Semarang yakni klaster semi modern UKM bakso yang ada di wilayah kota Semarang.

\subsection{Informan Penelitian}

Informan penelitian yang digunakan dalam kaitannya dengan model pembukuan sederhana berbasis klaster UKM Bakso di wilayah kota 
Dinamika Sosial Budaya, Vol 20, No. 1, Juni 2018, pp 16-29

p-ISSN: $1410-9859 \&$ e-ISSN: $2580-8524$

http://journals.usm.ac.id/index.php/jdsb

Semarang yakni pemilik UKM Bakso klaster Semi modern di wilayah kota Semarang .

Teknik pengumpulan data dalam penelitian ini melalui observasi, wawancara, dan dokumen. Observasi dilakukan ditempat lokasi UKM pada substansi proses menjalankan usaha berkait dengan pembukuan keuangan. Wawancara dilakukan pada pemilik UKM Bakso. Materi wawancara mendalam mencakup pembukuan keuangan, need informasi yang lebih mendalam pada informan penelitian untuk melakukan need assessment untuk keperluan model pembukuan sederhana berbasis klaster UKM Bakso di wilayah kota Semarang. Need assessment terkait pembukuan keuangan yang diperoleh dari informan dianalisis dan dilakukan triangulasi berdasarkan penelitan terdahulu, kajian referensi dan studi lapangan. Studi lapangan diperoleh melalui wawancara mendalam (indepth interview) dan dokumentasi jika diperlukan. Studi lapangan pada pemilik UKM dilakukan untuk: 1) mengetahui pembukuan keuangan yang telah dilakukan oleh klaster semi modern pemilik UKM Bakso, 2) model pembukuan sederhana bagi klaster UKM Bakso di wilayah kota Semarang; 3) keikutsertaan dan peran serta yang dilakukan institusi/stakeholders. Hasil triangulasi ini diperlukan untuk membuat model pembukuan sederhana berbasis klaster UKM Bakso di wilayah kota Semarang.

\subsection{Instrumen Penelitian}

Instrumen penelitian yang digunakan dalam penelitian model pembukuan sederhana berbasis klaster UKM Bakso di wilayah kota Semarang adalah peneliti sendiri pada key informan. Instrumen wawancara mendalam yang digunakan pada tahap studi pendahuluan untuk membuat model pembukuan sederhana berbasis klaster UKM Bakso di wilayah kota Semarang.

\subsection{Teknik Pengumpulan Data}


Dinamika Sosial Budaya, Vol 20, No. 1, Juni 2018, pp 16-29

p-ISSN: $1410-9859 \&$ e-ISSN: $2580-8524$

http://journals.usm.ac.id/index.php/jdsb

Semarang menggunakan uji kredibilitas melalui perpanjangan pengamatan

\section{Hasil dan Pembahasan}

Hasil penelitian kualitatif ini diperoleh dengan teknik wawancara secara mendalam dengan informan sebagai bentuk pencarian data dan dokumentasi langsung dilapangan yang kemudian peneliti analisis. Analisis ini sendiri fokus pada pemilik UKM Bakso klastersemi modern di kota Semarang, yang dikaitkan kepada beberapa unsur atau identifikasi masalah. Penelitian kualitatif merupakan prosedur penelitian yang menghasilkan data-data deskriptif berupa kata-kata tertulis atau lisan didasari oleh orang atau perilaku yang diamati. Pendekatannya diarahkan pada latar dan individu secara holistik (utuh). Untuk tahap analisis, yang dilakukan oleh peneliti adalah membuat daftar pertanyaan untuk wawancara, pengumpulan data, dan analisis data yang dilakukan sendiri oleh peneliti. Agar peneliti ini lebih obyektif dan akurat, peneliti mencari informasi-informasi tambahan dengan melakukan wawancara mendalam dengan informan untuk mendapatkan informasi terkait dengan pembukuan keuangan yang telah dilakukan pemilik UKM Bakso klaster semi modern di Kota Semarang.

\subsection{Profil UKM Bakso Klaster Semi Modern}

Usaha bakso mulai muncul di Semarang sekitar tahun 1980, dimana pada waktu itu banyak pendatang yang berasal dari daerah Solo, Wonogiri dan Klaten mencoba peruntungan dengan mulai usaha bakso di kota Semarang. Usaha bakso dimulai dengan meracik hidangan bakso menjadi sesuatu yang istimewa dan banyak digemari masyarakat. Seiring perkembangan jaman, dibentuklah suatu paguyuban bakso APMISO
(Asosiasi Pedagang Mie dan Bakso), yang bertujuan untuk merangkul semua pedagang bakso yang ada di Semarang untuk bersama- sama mengembangkan usahanya.

Pedagang bakso di kota Semarang kurang lebih berjumlah 1.000 pedagang yang terdiri dari tiga klaster yakni klaster Modern, klaster Semi Modern dan klaster Tradisional. Sebaran pedagang dalam klaster tersebut dapat digambarkan seperti pada diagram 1 di bawah ini klaster tradisional (669 pedagang gangster semi 26)

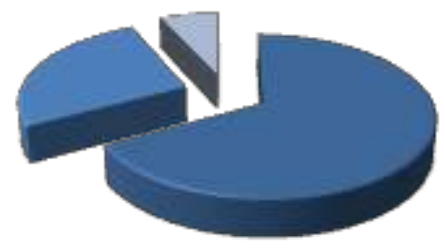

Gambar 2. Sebaran pedagang bakso dalam klaster Sumber:Data primer yang diolah 2 018Sebagai gambaran klaster pedagang bakso,dapat diuraikan sebagai berikut

1) Pedagang bakso klaster tradisional merupakan kelompok pedagang bakso yang menjajakan dagangannya dengan cara keliling kampung,bisa dengan gerobak bakso atau dijaman sekarang lebih banyak yang menjajakan bakso dengan berkeliling menggunakan sepeda motor. Jumlah pedagang bakso klater tradisional cukup banyak karena lebih mudah mengelolanya. Omzet per berkisar gerobaknya Rp.400.00,sampai dengan Rp.500.000,- 2) Pedagang bakso klaster semi modern merupakan kelompok pedagang bakso yang sudah mandiri karena sudah membuat dan menjual bakso sendiri dan sudah mempunyai warung bakso. Pada klaster ini pedagang bakso tidak lagi menjajakan dagangannya dengan berkeliling kampung tetapi 
Dinamika Sosial Budaya, Vol 20, No. 1, Juni 2018, pp 16-29

p-ISSN: $1410-9859 \&$ e-ISSN: $2580-8524$

http://journals.usm.ac.id/index.php/jdsb

menetap disuatu tempat yang dianggap strategis. Omzetnya berkisar Rp.2.000.000,- sampai dengan Rp.3.000.000,- 3) Pedagang bakso pada klaster modern merupakan kelompok pedagang bakso yang sudah mempunyai warung bakso yang lebih tertata rapi, cenderung higienis baik dilihat dari tempat maupun dari cara penyajian baksonya. Pada kelompok ini pedagan bakso lebih banyak yang membuka usahanya di mal dan pusat perbelanjaan dengan konsep mengusung makanan rakyat ke mal. Omzet pedagang pada klaster modern diatas Rp. 10.000.000,-

\subsection{Profil Informan}

Informan dalam penelitian ini yakni pedagang bakso yang sudah lama menjalankan usahanya dan memiliki banyak pengalaman dalam berdagang bakso di Kota Semarang. Informan tersebut sangat memahami bagaimana berdagang bakso, bisa diketahui saat proses wawancara dimana informan bisa menjelaskan

secara rinci berbagai permasalahan terkait dengan penelitian ini. Ada beberapa informan yang berhasil diwawancarai dan hanya empat informan yang mampu memberikan keterangan yang valid, reliabel dan obyektif. Profil ke empat informan tersebut yakni :

\section{Bapak Lasiman}

Bapak Lasiman telah mulai usaha bakso sejak tahun 1980, mulai usahanya dengan meracik sendiri bakso yang akan dijualnya dan dijajakan keliling kampung menggunakan gerobak di daerah Sampangan Semarang, sampai pada akhirnya memperoleh tempat yang strategis di daerah Banyumanik Semarang, usaha baksonya diberi nama Punakawan Petruk yang berhasil meraih kesuksesan. Pada tahun 1990 bapak Lasiman berhasil mengkoordinir semua pedagang bakso yang ada di kota Semarang, semua pedangang/pemilik UKM bakso ini dikumpulkan dalam satu paguyuban yang diberi nama APMISO (Asosiasi Pedangan Mie dan Bakso).

2. Ibu Purwati

Ibu Purwati memulai usaha bakso pada tahun 1980 dengan berkeliling kampung di daerah Citarum dan sekitarnya. Ibu Purwati beserta suaminya meramu sendiri semangkok bakso yang akan dijual, supaya bakso yang dijualnya mampu menarik pelanggan untuk kembali lagi membeli baksonya. Seiring perkembangan waktu ibu Purwati mendapatkan tempat yang strategis untuk berjualan yakni diperempatan Jl. Citarum dan diberi nama Bakso Mawardi. Usahanya berkembang dengan pesat, sampai saat ini telah mempunyai beberapa cabang di Kota Semarang yang dikelola okeh keluarga Ibu Purwati Sendiri.

3. Bapak Edy

Pada tahun 1997 Bapak Edy mulai membuka usaha baksonya di sebuah ruko di daerah Bangetayu Semarang karena kegigihannya dalam menjalankan usahanya pada saat ini Bapak Edy telah mempunyai beberapa cabang di daerah Mranggen dan Demak.

4. Bapak Ahmad

Bapak Ahmad adalah pemilik UKM bakso Wonogiri di daerah Mugas Semarang. Pertama kali masuk kota Semarang pada tahun 1985, mulai usahanya dari nol dengan ikhtiar dan tekad yang kuat akhirnya Bapak Ahmad merasakan manisnya perjuangan. Saat ini Bapak Ahmad memiliki warung Bakso di daerah Mugas Semarang. Profil key informan dalam peneliitian 
Dinamika Sosial Budaya, Vol 20, No. 1, Juni 2018, pp 16-29

p-ISSN: 1410-9859\& e-ISSN: 2580-8524

http://journals.usm.ac.id/index.php/jdsb

berkenaan dengan masalah yang diteliti dapat

dilihat pada tabel 4.1. sebagai berikut :

Tabel 4.1 Tabel Profil Informan

\begin{tabular}{|c|l|l|c|}
\hline No & N & U & Mulai Usaha \\
\hline 1 & Lasiman & Ketua APMISO & 2000 \\
. & & Bakso Punakawan & 1978 \\
\hline 2 & Purwanti & Bakso Mawardi & 1980 \\
\hline 3 & Edy & Bakso SOLO & 1982 \\
\hline 4 & Ahmad & Bakso Wonogiri & 1985 \\
\hline
\end{tabular}

Sumber :Data Primer yang diolah 2018

\subsection{Pembahasan}

Analisis deskriptif data penelitian adalah analisis pada data yang diperoleh dari hasil wawancara dengan 4 orang sebagai informan kunci yang terdiri dari pemilik UKM bakso klaster semi modern dan ketua Asosiasi Pedagang Mie dan Bakso di kota Semarang. Berdasarkan hasil wawancara dengan informan, peneliti menganalis pembukuan keuangan yang telah dilakukan oleh pemilik UKM Bakso Klaster Semi Modern yang ada dikota semarang untuk membuat suatu desain pembukuan sederhana bagi UKM Bakso Klaster Semi Modern.

\subsubsection{Pembukuan Keuangan UKM Bakso Klaster Semi Modern}

Setiap usaha pasti memiliki transaksi keuangan setiap harinya. Untuk mengelola keuangan dengan baik, pemilik usaha harus melakukan pencatatan keuangan untuk melihat biaya apa saja yang masuk dan keluar. Pencatatan yang baik akan memengaruhi keberhasilan dalam usaha yang dijalankan. Proses pencatatan keuangan biasanya sering dikenal dengan proses pembukuan. Pembukuan keuangan menjadi salah satu masalah yang seringkali terabaikan oleh para pemilik UKM Bakso di kota Semarang, khususnya berkaitan dengan penerapan kaidah-kaidah pengelolaan

keuangan dan pembukuan keuangan yang benar. Masalah pembukuan keuangan biasanya timbul dikarenakan pengetahuan dan informasi mengenai pembukuan keuangan sangat terbatas, latar belakang

pendidikan para pemilik UKM juga mempengaruhi pengetahuan para pemilik UKM (Kamyabi, Y., \& Devi, S. 2014). Pengetahuan untuk mengelola keuangan dapat membantu pemilik UKM bakso untuk membangun usaha yang berkelanjutan dan mampu mengambil keputusan dengan baik (Umeji \& Obi, 2014).

Pengelolaan keuangan menjadi salah satu aspek penting bagi kemajuan usaha yang dijalankan. Pengelolaan keuangan dapat dilakukan melalui pembukuan yang sesuai dengan standar akuntansi yang berlaku. Pembukuan keuangan yang sesuai dengan standar akuntansi merupakan proses sistematis untuk menghasilkan informasi yang menyangkut kondisi keuangan, kinerja karyawan, dan perubahan kondisi keuangan perusahaan yang dapat dimanfaatkan pengusaha untuk pengambilan keputusan (Setyorini, et.al.2010).

Berkembangnya UKM Bakso di Kota Semarang ternyata tidak diimbangi dengan pengelolaan keuangan yang baik. Salah satu kegiatan dalam pengelolaan keuangan, pemilik UKM dapat membuat pembukuan terkait dengan usahanya. Untuk mendapatkan informasi tentang pembukuan keuangan UKM Bakso khususnya klaster semi modern peneliti telah mewawancarai beberapa pemilik UKM Bakso klaster semi modern. Hasil wawancara dengan key informan menunjukkan bahwa hampir semua pemilik UKM bakso klaster semi modern belum mempunyai pengetahuan yang baik terkait dengan pencatatan keuangan, sehingga menganggap 
Dinamika Sosial Budaya, Vol 20, No. 1, Juni 2018, pp 16-29

p-ISSN: $1410-9859 \&$ e-ISSN: $2580-8524$

http://journals.usm.ac.id/index.php/jdsb

pencatatan keuangan tidaklah penting bagi

kemajuan usahanya. Hasil penelitian Maseko dan

Manyani (2011) mengungkapkan bahwa

pelaksanaan pembukuan akuntansi untuk

menyediakan laporan keuangan yang informatif

merupakan hal yang masih sulit bagi UKM. Hal ini

disebabkan karena keterbatasan pengetahuan dalam

pembukuan akuntansi, rumitnya proses akuntansi,

dan anggapan bahwa laporan keuangan bukanlah

hal yang penting bagi UKM. Walaupun pemilik

UKM bakso pada klaster semi modern mempunyai keterbatasan pengetahuan dalam pembukuan akuntansi, pemilik UKM bakso enggan mempekerjakan orang yang benar-benar memahami pembukuan keuangan, hal ini disebabkan biaya yang harus dikeluarkan terlalu mahal. Hasil penelitian ini mendukung penelitian Senzu (2017) yang mengungkapkan bahwa mayoritas pemilik UKM sangat setuju dengan pencatatan keuangan, kurang tertib dan teraturnya pencatatan merupakan akibat dari kurangnya pengetahuan keuangan dan pencatatan keuangan yang buruk sebagian besar disebabkan oleh biaya tinggi yang harus dikeluarkan pemilik UKM untuk membiayai karyawan yang mempunyai kualitas yang baik dalam pengelolaan keuangan dan tidak membuat kinerja keuangan usahanya menjadi lebih baik (Danford, 2014).

Minimnya pengetahuan akuntansi menjadi alasan bagi pemilik UKM Bakso pada klaster semi modern untuk tidak membuat pembukuan keuangan yang tertib dan teratur, pembukuan keuangan yang selama ini dilakukan merupakan catatan keuangan yang sangat sederhana dan tidak sistematis. Kondisi ini seperti di ungkapkan oleh Said (2008) yang menyatakan bahwa Sebagian besar UKM masih belum menyelenggarakan pembukuan keuangan dan pelaporannya dengan baik. Pemilik UKM memandang akuntansi merupakan sesuatu yang sangat sulit untuk dijangkau. Bagi mereka, suatu proses akuntansi tidak terlalu penting untuk diterapkan. Hal terpenting bagi mereka adalah cara menghasilkan laba sebanyak mungkin dari usaha yang dijalankan tanpa direpoti dengan masalah pembukuan/ akuntansi (Idrus, 2000).

Pemilik UKM bakso pada klaster semi modern menyadari arti penting penyusunan laporan keuangan, walaupun belum semua pemilik UKM bakso pada klaster semi modern melaksanakan pembukuan secara konsisten. Beberapa alasan yang diungkap oleh pemilik UKM Bakso antara lain: 1) Pemilik UKM merasa tidak membutuhkan informasi akuntansi. Hal ini sesuai dengan penelitian yang dilakukan oleh Pinasti $(2001 ; 2007)$ yang mengungkapkan bahwa informasi akuntansi tidak penting alasan yang dikemukakan oleh para pengusaha kecil tersebut adalah pengusaha kecil merasa terlalu direpotkan dengan penyelenggaraan catatan akuntansi tersebut.

2) Kebutuhan akan penyelenggaraan catatan keuangan dianggap hanya membuang waktu dan biaya. Yang terpenting bagi pemilik UKM yakni cara menghasilkan laba sebanyak mungkin dari usaha yang dijalankan tanpa dibebani dengan masalah pembukuan. Keberhasilan suatu usaha bergantung pada pembuatan dan pencatatan keuangan yang efektif. Hasil penelitian ini mengisyaratkan bahwa para pemilik UKM menganggap bahwa

pembukuan keuangan mempunyai manfaat yang lebih kecil dibandingkan biaya yang harus dikorbankan ketika menyelenggarakan praktik pembukuan secara tepat secara tepat. Pembukuan keuangan dalam suatu usaha mempunyai peranan yang sangat penting bagi UKM karena pembukuan 
Dinamika Sosial Budaya, Vol 20, No. 1, Juni 2018, pp 16-29

p-ISSN: $1410-9859 \&$ e-ISSN: $2580-8524$

http://journals.usm.ac.id/index.php/jdsb

keuangan dapat menjadi tolak ukur kesuksesan usaha dan membantu pemilik UKM memperoleh informasi yang baik terkait dengan kodisi perusahaan dengan demikian pemilik UKM mampu mengambil keputusan dengan tepat (David.et.al., 2009).

Agar pemilik UKM dapat melakukan pembukuan keuangan diperlukan perencanaan yang matang dalam memberikan pemahaman dan pelatihan pada pemilik usaha kecil dalam membuat pembukuan keuangan perusahaannya. Pelatihan sangat bermanfaat bagi pemilik UKM Bakso Klaster Semi modern untuk meningkatkan pengetahuan, keterampilan dan kompetensi sumber daya manusianya. Dengan menggunakan metode pelatihan pembukuan keuangan yang tepat dapat mengantar pelaku usaha kecil meraih kesuksesan.

\subsubsection{Model Hipotetik Pembukuan Sederhana UKM Bakso Klaster Semi Modern}

Temuan di lapangan dalam kaitannya dengan model pembukuan sederhana menunjukkan bahwa pembukuan yang dilakukan pemilik UKM bakso klaster semo modern belum sesuai dengan standar akuntansi yang berlaku kondisi ini disebabkan kurangnya pengetahuan pemilik UKM Bakso klaster semi modern tentang pembukuan sederhana. Fatoki (2014) mengungkapkan bahwa sebagian besar pemilik usaha mikro tidak mempunyai pengetahuan secara formal berkait dengan perencanaan keuangan, penganggaran dan pengendalian. Pembukuan merupakan proses pencatatan semua transaksi baik transaksi pendapatan dan pengeluaran, transaksi penjualan, barang yang dilakukan oleh setiap perusahaan atau dalam usaha. Hasil pembukuan keuangan, akan menjadi sebuah laporan keuangan, yang kemudian dapat menjadi acuan untuk melihat kondisi usaha

yang dijalankan dan dapat digunakan untuk pengambilan keputusan usaha yang dijalankan. Wolmarans. H., (2015) mengungkapkan bahwa usaha-usaha kecil akan menjadi sukses jika pelaku usaha kecil fokus pada pengelolaan keuangan

baik untuk jangka pendek maupun jangka panjang. Penyusunan pembukuan sederhana untuk UKM Bakso klaster semi modern terbagi dalam beberapa tahap yang mencakup 1) mengumpulkan seluruh data transaksi, 2) Membuat jurnal transaksi, tahapan selanjutnya adalah memasukan nilai transaksi ke dalam jurnal transaksi berdasarkan data-data transaksi yang sudah di analisis. 3) Membuat buku besar, buku besar adalah kumpulan dari jurnal-jurnal transaksi. 4) Membuat laporan keuangan yang terdiri dari 1) laba rugi merupakan aktivitas usaha yang di lakukan berupa hasil jumlah penjualan dan biaya yang harus di keluarkan. 2) perubahan modal yakni laporan yang menunjukan jumlah modal yang digunakan dalam menjalankan usaha, 3) neraca yakni laporan keuangan yang menggambarkan mengenai aset atau harta perusahaan, hutang, dan modal yang dimiliki oleh perusahaan dalam periode tertentu, 4) arus kas merupakan petunjuk dana masuk dan dana keluar usaha yang sedang jalankan. Desain model pembukuan sederhana bagi pemilik UKM Bakso Klaster semi modern dibuat sesuai transaksi yang selama ini dilakukan oleh pemilik UKM Bakso seperti pada gambar 3. di bawah ini

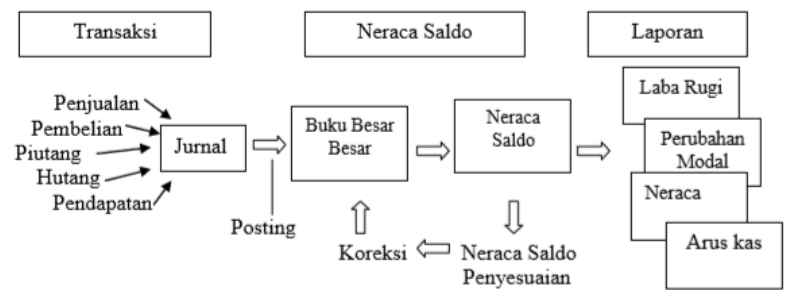

Gambar 3. Pembukuan Sederhana bagi UKM Bakso Klaster Semi Modern 
Dinamika Sosial Budaya, Vol 20, No. 1, Juni 2018, pp 16-29

p-ISSN: 1410-9859\& e-ISSN: 2580-8524

http://journals.usm.ac.id/index.php/jdsb

Gambar 3. Pembukuan Sederhana bagi UKM Bakso

Klaster Semi Modern

\section{Simpulan dan Saran}

\subsection{Simpulan}

Berdasarkan hasil penelitian dalam kaitannya dengan model pembukuan sederhana

UKM Bakso Klaster Semi Modern di kota

Semarang, diperoleh beberapa kesimpulan sebagai berikut:

1. Pelaksanaan pembukuan keuangan pada pemilik UKM Bakso Klater Semi modern di

Kota Semarang masih masih belum sesuai dengan standar akuntansi yang ada, karena pengetahuan pembukuan keuangan yang rendah.

2. Desain model pembukuan keuangan sederhana perlu disesuaikan berdasarkan analisa kebutuhan yang mencakup pengelolaan keuangan dan transaksi keuangan yang selama ini dilakukan pemilikUKM Bakso klaster semi modern.

\subsection{Saran}

Beberapa hal yang dapat direkomendasikan dari penelitian dalam kaitannya dengan model pembukuan keuangan sederhana bagi pemilik UKM Bakso klaster semi modern di kota Semarang, sebagai berikut:

1. Diperlukan pelatihan pembukuan sederhana untuk mempermudah pemilik

UKM Bakso Klaster semi modern dalam membuat pembukuan sedrhana.

2. Pengintensifan keterlibatan stakeholder (pemerintah, perbankkan, lembaga keuangan, Perguruan Tinggi) dalam meningkatkan pengetahuan keuangan khususnya dalam membuat pembukuan sederhana sangat diperlukan. 
Dinamika Sosial Budaya, Vol 20, No. 1, Juni 2018, pp 16-29 p-ISSN: 1410-9859\& e-ISSN: 2580-8524

http://journals.usm.ac.id/index.php/jdsb

Maseko, N. and O. Manyani. 2011. Accounting Practices of SMEs in Zimbabwe: An Investigative Study of Record Keeping for Performance Measurement (A Case Study of Bindura). Journal of Accounting and Taxation,3(8), 171-181.

Mardiasmo. 2000. Akuntansi Keuangan Dasar Jilid 1 Edisi 3. Yogyakarta: BPFE UGM

Milles, M.B. and Huberman, M.A. 1984. Qualitative Data Analysis. London: Sage Publication Miles, B. Mathew dan Michael Huberman. 1992. Analisis Data Kualitatif Buku

Baru.Jakarta: UIP. Munawir, 2004. Analisis Laporan Keuangan, Liberty, Yogyakarta.

Pinasti, M. 2001. Penggunaan Informasi Akuntansi dalam Pengelolaan Usaha Para Pedagang Kecil di Pasar Tradisional Kabupaten Banyumas. Jurnal Ekonomi, Bisnis, dan Akuntansi. Vol 3. No. 1. Pp. 10-17.

Pinasti. 2007. Pengaruh Penyelenggaraan dan Penggunaan Informasi Akuntansi Terhadap Persepsi Pengusaha Kecil atas Informasi Akuntansi: Suatu Riset Eksperimen. Jurnal Riset Akuntansi Indonesia. Vol. 10. No.3. Pp.321-331

Rahamon. 2014. The Analysis of the impact of Accounting Records Keeping on the Performance of the Small Scale Enterprises. International Journal of Academic Research in Business and Social Sciences January 2014, Vol. 4, No. 1 ISSN: 2222-6990

Senzu and Ndebugri.2018. Examining business performance ofmicro, small and medium scale enterprise through accounting records keeping; case study in Ghana. MPRA Paper No. 84022, posted 22 January 2018 18:30 UTC

Setyorini, Istiningrum, Nugroho, Dan Sagoro, 2010. Pelatihan akuntansi UMKM bagi Usaha Mikro Kecil Menengah (UMKM) Untuk Meningkatkan Kinerja KeuanganPerusahaan. Yogyakarta.

Tambunan,Tulus.2000.Perdagangan Internasional dan Neraca Pembayaran.

Jakarta: Pustaka LP3S

Tri Widiastuti, dkk. 2017. Analisis Kinerja keuangan UKM Bakso di Wilayah

Kota Semarang. LP2M Universitas Semarang.tidak dipublikasi.

Umeji, A. U., \& Obi, C. A. (2014) Cost accounting skills needs of small business operators. American Journal of Industrial and Business Management, 4, 246257.doi:10.4236/ajibm.2014.45032

Urata, Shujiro, Prof. 2000. Policy Recommendation for SME Promotion in the

Republic of Indonesia, JICAReport, Jakarta

Vanauken.et.al.,2016.Turkish SMEs' Use of Financial Statements for Decision

Making. The Journal of Entrepreneurial Finance Volume 19

http://www.depkop.go.id/berita-informasi/datainformasi/data-umkm/, diunduh10

Januari 2018 
